\title{
Article
}

\section{The Kaohsiung Incident in Taiwan and Memoirs of a Foreign Big Beard, written by J. Bruce Jacobs [Book Review]}

\author{
Alsford, Niki Joseph paul \\ Available at https://clok.uclan.ac.uk/21731/ \\ Alsford, Niki Joseph paul orcid iconORCID: 0000-0003-1939-4313 (2018) The \\ Kaohsiung Incident in Taiwan and Memoirs of a Foreign Big Beard, written by J. \\ Bruce Jacobs [Book Review]. International Journal of Taiwan Studies, 1 (1). pp. \\ 238-240. ISSN 2468-8797
}

It is advisable to refer to the publisher's version if you intend to cite from the work. http://dx.doi.org/10.1163/24688800-00101016

For more information about UCLan's research in this area go to http://www.uclan.ac.uk/researchgroups/ and search for <name of research Group>.

For information about Research generally at UCLan please go to http://www.uclan.ac.uk/research/

All outputs in CLoK are protected by Intellectual Property Rights law, including Copyright law. Copyright, IPR and Moral Rights for the works on this site are retained by the individual authors and/or other copyright owners. Terms and conditions for use of this material are defined in the policies page.

\section{CLoK}

Central Lancashire online Knowledge www.clok.uclan.ac.uk

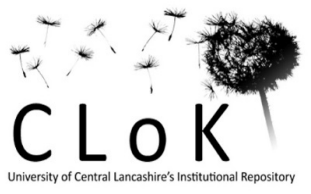


Jacobs, J. Bruce, The Kaohsiung Incident in Taiwan and Memoirs of a Foreign Big Beard, 2016, Leiden, BRILL, xii, 178 pp. €82 (hb)

2017, in the modern political history of Taiwan, marks a number of important observances. It has been seventy years since the 228 Incident (a violently suppressed anti-government uprising), and thirty years since the lifting of martial law. The intervening forty years witnessed enormous change on the island, however, the documenting of this change has for the most part been focused on the island's economic and political transitions. During the 1950s, Taiwan underwent multiple land reform and community development programmes, principally under the aegis of the Sino-American Joint Commission on Rural Reconstruction. The notion of 'developing agriculture by virtue of industry and fostering industry by virtue of agriculture 以農業培養工業，以工業發展農業', had by 1961 led to two four-year economic plans. The period between 1963 and 1973, considered 'a golden age' of economic growth in Taiwan, saw the island become one of the four Asian tigers (the others being South Korea, Singapore, and Hong Kong). This economic success story, often referred to as the 'Taiwan Miracle', arguably aided the island in its transformation towards a liberal democracy.

This economic shift, which opened up more opportunities within the labour market, sparked a significant rise in social mobility. By the late 1970 s and early 1980s, the new middle class of Taiwan, and the free enterprise that had permitted their emergence, become important markers in the people's demand for greater rights and more democratic processes. The subsequent emergence of the social impact of civil society in Taiwan has until only recently been largely absent from this documentation of change. Yet, this narrative was a major turning point in the history of democracy in Taiwan, the foundations of which can arguably be found in the Kaohsiung Incident on 10 December 1979: the point of departure for Jacobs' book.

To commemorate Human Rights Day (a date chosen to echo the United Nations General Assembly's adoption of the Universal Declaration of Human Rights), a demonstration was organised by the Formosa Magazine, led by Huang Hsin-chieh and other members of the Tangwai (lit. 'outside the party'), whose purpose was to promote and demand democracy. The incident that occurred on 10 December had its roots the day earlier when two campaign wagons (dispatched by the Formosa Magazine) broadcast the 'Human Rights Forum'. The police held up the procession and two of the volunteers were arrested. This resulted in a number of the Tangwai gathering outside the Gushan branch of the Police Security Bureau where the two were being held. The outrage felt at the arrest prompted a number of the Tangwai and its followers to attend the following day's demonstration even though they had not previously planned to. On the 10th, four hours before the planned gathering (between 2 and 3 p.m.), the authorities - including the military police, the army, and the police took up positions in the vicinity of where the protest was due to happen. As the event unfolded, the military police began to close in on the demonstrators. Panic started to set in as demonstrators clashed with the authorities. The Kuomintang (the then ruling authority), as a result, used the incident as an excuse to arrest well-known opposition leaders.

The title of Jacobs' book - The Kaohsiung Incident in Taiwan and Memoirs of a Foreign Big Beard immediately informs us that we're in the right territory. Here we have a carefully negotiated balance of scholarly evenness and personal memoir. The monograph is attentively divided into two narratives. Drawing upon multiple sources, the contextual, scholarly section details the events leading up to the incident, its aftermath, and the implications of that fateful day. The author's own participation in the events draws the reader in. From within, you get the sense of theatre that other accounts of the incident have not quite achieved. 
The greater part of the first section gives a detailed analysis of the military trials of the eight key defendants (known as the Kaohsiung Eight), and the thirty-three civilian trials. The 'from below' element of this detailed description provides a useful platform from which to explore the intellectual history of the Taiwan democratic movements. The central premise of this enables a greater consideration of the knowledge that was created, discussed, written, and most importantly practised, by Taiwanese intellectuals during the martial law period. In reference to the trials this is particularly evident in the identity of some of the defence lawyers. Chief among those are Chen Shuibian (for Huang Hsin-Chieh) and Su Tseng-chang (for Yao Chia-wen) (p.66). The former became President (2000-200), while the latter was chairman of the Democratic Progressive Party (2012-14). What is more, through the microhistorical dissection of the events, Jacobs is able to highlight key divides within the Tangwai movement (p.14), struggles from which would become increasingly intense during the first five years of the founding of the Democratic Progressive Party. Emphasis on these divisions is important as new research begins to reflect more on the traditional left elements within Taiwan politics. As the first section ends, Jacobs signs off with the words of poet Li Min-yung, that Taiwan must 'allow the flowers of the wounds to blossom soon 讓傷口的花早日綻放'; words that remain very topical as the government today, under the Democratic Progressive Party, pushes forward its election mandate for transitional justice.

The second part of this narrative is where I believe its true value lies. As scholars of Taiwan studies, we are blessed to have a number of academics who at one point or another were present in Taiwan during its pivotal transitional periods. Hearing their stories regularly reinforces one's own passion for the study of this island. Yet beneath this layer is also another important element: one of connected histories; a term made popular by Sanjay Subrahmanyam in his 1997 essay of the same title. The history of democracy in Taiwan is integrative. It is entangled and entwined with many other histories. It is both transnational as well as transcultural. Jacobs' personal memoir is not the only one -- Linda Arrigo and Lynn Miles are two others that immediately spring to mind -- yet the marriage of emotional memoir to scholarly context in this volume is exemplary.

As such, this book is an important text that is useful not just for the study of Taiwan and the region, but also for comparative research on microhistorical inquiries of authoritarianism and protest as well as connected or transcultural histories. 